\title{
ANALISIS HALAMAN DARKWEB UNTUK MENDUKUNG INVESTIGASI KEJAHATAN
}

\author{
Muhammad N Bahreisy ${ }^{1}$, Ridho Rahmadi ${ }^{2}$, Yudi Prayudi ${ }^{3}$ \\ ${ }^{1}$ Program Studi Magister Teknik Informatika \\ ${ }^{2}$ Universitas Islam Indonesia \\ ${ }^{3}$ Universitas Islam Indonesia \\ Email: 16917113@students.uii.ac.id, ${ }^{2}$ ridho.rahmadi.ac.id, ${ }^{3}$ prayudi @uii.ac.id
}

(Naskah masuk: 9 Juni 2020, diterima untuk diterbitkan: 27 Juli 2020)

\begin{abstract}
Abstrak
Dark Web merupakan konten online yang terenkripsi dan hanya dapat di akses menggunakan jaringan khusus seperti TOR (The Onion Router). Saat ini perkembangan konten online menjadi perhatian serius karena pertumbuhan bagi kegiatan dan layanan terlarang seperti penjualan barang illegal, narkoba dan pornografi anak. Kejahatan komputer dalam dunia internet mendorong banyaknya pertumbuhan transaksi jual beli barang-barang illegal yang dijual dipasar gelap, transaksi yang menguntukan namun illegal menarik perhatian. Dark Web merupakan salah satu media yang digunakan. Dark Web merupakan istilah web yang dikategorikan sebagai Deep Web yang berdomain .onion yang tidak dapat ditemukan di mesin pencarian seperti google, yahoo dan bing. Analisis halaman-halaman Dark Web dalam mendukung investigasi kejahatan diusulkan sebagai solusi untuk memecahkan masalah tersebut. Konsep ini berupa analisis halaman-halaman Dark Web yang diharapkan mendukung dalam investigasi kejahatan. Dalam penelitian ini akan dilakukan analisis dari hasil capturing halaman-halaman Dark Web. Berdasarkan hasil analisis kemudian diklasifikasikan berdasarkan kategori dengan merefleksikan pada grafik sesuai klasifikasi. pada penelitian ini didapatkan informasi yang penting untuk melakukan analisis halaman-halaman Dark Web, seperti informasi tentang jumlah frekuensi kata tertinggi dan vendor yang berkaitan dengan hal tersebut..
\end{abstract}

Kata kunci: Dark Web; illegal; TOR (The Onion Router)

\section{THE ANALYSIS OF THE DARK WEB PAGES IN SUPPORT CRIME INVESTIGATION}

\begin{abstract}
Dark Web is an encrypted online content that can only be accessed using a dedicated network such as TOR (The Onion Router). Nowadays the development of online content is a serious concern because of growth for illegal activities and services such as the sale of illegal goods, drugs and child pornography. Computer crimes in the Internet world encourages the growing number of trade transactions for illegal goods that are sold in dark markets, transactions that are illegal but attract attention. Dark Web is one of the media used. Dark Web is a web term that is categorized as a Deep Web that has domain .onion that cannot be found in search engines such as Google, Yahoo and Bing. The analysis of the Dark Web pages in support crime investigation is proposed as a solution to solve the problem. This concept constitutes the analysis of Dark Web pages that are expected to support the investigation of crimes. In this study will be conducted analysis of the results capturing the pages of Dark Web. Based on the analysis results are then classified by category by reflecting on the chart according to classification. In this study obtained information that is important for conducting the analysis of Dark Web pages, such as information about the highest number of word frequency and vendor related to it.
\end{abstract}

Keywords: Dark Web; illegal; TOR (The Onion Router)

\section{PENDAHULUAN}

Indonesi merupakan salah satu negara dengan pengguna internet yang cukup tinggi[1] Lahirnya internet dengan membuat penggunanya dapat berkomunikasi secara geografis berjauhan, namun seolah-olah mereka berada berdekatan. Kehadiran internet memberikan banyak kemudahan bagi penggunanya muali dari mudahnya bertukar informasi sampai memanfaatkan, sebagai sarana komunikasi untuk menawarkan barang atau jasa yang 
melanggar hukum, munculnya beberapa kasus cybercrime di Indonesia, seperti hacking beberapa situs, pencurian kartu kredit, pornografi, penjualan barang illegal, menyadap transmisi data orang lain, misalnya email dan memanipulasi data dikomputer yang telah disisipkan menggunakan perintah yang tidak dikehendaki.

Ranah dunia maya begitu dinamis dan memunculkan ragam area yang menarik untuk dikaji lebih dalam. Word Wide Web yang lebih akrab ("Clear Web") relatif mudah untuk dilalui, menggunakan browser google, yahoo dan bing web. Namun sesungguhnya Word Wide Web hanya menyumbang Sebagian dari lalu lintas internet, sementara konten diinternet tidak terindeks di sebut sebagai Deep Web [2]. Bagian yang tidak terindeks dan sengaja disembunyikan dan tidak dapat diakses oleh browser standar disebut sebagai Dark Web [3]Untuk mengakses Deep web yang kita perlukan ilmu tentang mesin pencarian seperti intute, DeepPeep, Scirus dan WWW Virtual Library.

Dark web yang merupakan bagian dari Deep web yang tidak dapat ditemukan di mesin pencarian seperti google, yahoo dan bing. Dalam hal ini ada beberapa situs jual beli narkotika, pornografi, peretasan, situs kekerasan. Hampir semua dari situs Deep Web yang dikenal dengan dot onion namun situs berdomain onion tersebut bukan Deep Web secara keseluruhan dot onion merupakan sebagian kecil dari Deep Web yang biasa disebut Dark Web atau sisi gelap internet. Deep Web merupakan bagian dari internet tetapi tidak termasuk ke bagian internet yang dapat diakses mesin pencarian seperti google.com.

Sifat terarang dari bisnis yang dilakukan pada pada Dark Web banyak pengguna memutuskan untuk mengenkripsi komunikasi mereka. Pesan yang paling umum program enkripsi yang digunakan adalah $P G P$ (pretty good privacy) [4].

Berdasarkan penelitian yang dilakukan oleh Wilson Center mengenai The Deep Web and The Darknet pada tahun 2015 dikatakan bahwa Google saat ini sebagai mesin pencarian terbesar hanya mengindeks 4-16 persen dari Surface web. Sedangkan Deep web lebih besar 400-500 kali dari Surface web, dan menurut penelitian yang telah dilakukan [5]bahwa Dark Web terbukti sebagai web yang memfasilitasi penjualan barang-barang terlarang seperti "drugs", situs penyewaan pembunuhan dan lain sebagianya. .

Dark Web merupakan istilah umum bagi web dimana orang dapat berinteraksi secara bebas tanpa khawatir atas pengawasan pemerintah. Situs-situs yang dikategorikan dalam Dark Web dijaga oleh mekanisme enkripsi yang memungkinkan pengguna menggunjungi situs secara anonim. Beberapa peneliti telah melakukan penelitian terkait Dark web yaitu [13-15] baik dalam marketplace untuk proses investigasi [13] selain itu dilakukan analisis sentiment [14] [15]. Pada Dark Web alamat situs yang dapat dikunjungi tidak diketik secara gambalang seperti googl.com melaikan mengetik alamat url yang lebih Panjang dan kompleks sebagia contoh, apabila pengguna ingin mengkses Dark web pengguna harus menggunakan browser Tor sebagai contoh alamat situs Dark web yaitu pada web Hidden Wiki seperti url alamat kpvz7ki2v5agwt35.onion[6].

Berdasarkan pemaparan dari di atas terkait Dark Web, dapat diketahui bahwa banyak situs Dark Web terdapat tindak kejahatan. Sulitnya menganalsisi Dark Web sehingga diperlukan analsisi data pada halaman-halaman Dark Web dalam mendukung investigasi kejahatan. Oleh sebab itu penulis berasumsi bahwa menganalisa halaman-halaman pada Dark Web diharapkan mendapatkan informasi dalam mendukung investigasi kejahatan

\section{METODE PENELITIAN}

a. Bukti Digital

Keberadaan barang bukti digital menjadi barang bukti penting dalam sebuah kasus kejahatan komputer. Bukti digital dimulai sebagai data elektronik, baik dalam bentuk transaksi, dokumen, atau beberapa jenis media seperti rekaman audio atau video[7]. Transaksi termasuk transaksi keuangan yang dibuat selama proses pembelian, membayar tagihan, menarik uang tunai, dan bahkan menulis cek. Walaupun menulis cek mungkin tampak sebagai metode kuno yang tidak bersifat digital atau elektronik, pemrosesan cek tertulis elektronik dan disimpan di bank atau perusahaan kartu kredit. Hampir setiap jenis transaksi hari ini akhirnya didigitalkan di beberapa titik dan menjadi barang bukti digital: kunjungan dokter, proyek konstruksi, mengisi resep, mendaftarkan anak di tempat penitipan anak, dan bahkan membawa hewan peliharaan untuk mendapatkan suntikan rabies.

\section{b. Dark Web}

Jika menganggap web sebagai lautan data, sebagian besar dari kita berinteraksi dengen Surface Web yang tergolong mudah ditelusuri dan terindeks di mensin pecari yang bisa digunakan seperti google, yahoo dan bing. Berbeda dengan Dark Web yang biasa digambarkan segmen dari web yang mendalam digambarkan sebagai web tersembunyi yang menyatakan bahwa pengguna web tidak dapat dengan mudah mengakses Dark Web dengan harapan mereka dapat berbagi informasi dan file dengan sedikit resiko terdeteksi[8]. Dark Web merupakan konten Word Wide Web yang berada di sisi lain dari internet yang tidak bisa diakses melalui mesin pencari yang biasa digunakan pada umumnya. Dark Web dalam paradigma realitas internet diibaratakan seperti lingkungan yang buruk didunia nyata, yang mana kecenderungan perilaku kejahatan siber lebih banyak seperti halnya dunia nyata, ada kemungkinan orang baik berada dilingkungan buruk[6]. Namun kecenderungan kearah aktivitas illegal lebih besar. 
Dark Web bisa juga disebut Darknet bagian dari Deep Web yang hanya bisa diakses menggunakan sesuatu yang khusus untuk dapat mengksesnya, mislanya menggunakan proxy atau autentikasi khusus untuk dapat mengakses Dark Web, URL situs yang berdomain ".onion" tersebar diantara server diseluruh dunia dan tidak terpusat disuatu tempat. Dark Web merupakan bagian kecil dari Deep Web yang isinya disembunyikan untuk tujuan tertentu. Dark Web meminta alat khusus untuk dapat mengakses kontennya dan memerlukan tingkat enkripsi tertinggi. Dark Web menampung aktivitas criminal dan sering digunkan oleh jurnalis dan orang lain untuk bertukan informasi sensitif [9].

Deep Web dan Darknet tidak memiliki lokasi khusus akan tetapi terdistribusikan di seluruh internet dan berbagi satu kesamaan yaitu tersembunyi dari mesin pencari dari pengguna internet biasa[10]. Orang dapat mencari situs darknet hanya dengan mengetik .onion atau .onion sites atau menemukan website yang sama seperti Tor Hidden Wiki, Onion.city dan DNStats. Pengguna memerlukan software khusus untuk mengaksesnya. Mengkategorikan teknik forensik dalam penelitiannya untuk darknet forensic menjadi dua kategori yaitu TOR forensics dan Bitcoin forensics.

Menurut penelitiaan yang dilakukan oleh[10] menjelaskan beberapa kategori level dalam Deep web mulai dari 1 samapi dengan level 5 penjelasan kategori level dalam Deep web sebagai berikut .

1. Level 1dalah bagian web biasa yang paling umum dan dapat memahaminya secara umum. Akan tetapi bukan untuk public di web

2. Level $\mathbf{2}$ adalah bagian web yang dikenal sebagai surface web, layanan seperti Reddit, Digg, dan email termasuk didalamnya. Konten-konten pendukung sosial lainnya dapat ditemukan di tingkat ini karena pada dasarnya merupakan platform komunikasi dan mencapainya tidak sulit.

3. Level 3 disebut Bargie web yaitu layanan selain $W W W$ atau $W e b$ yang dapat dikategorikan dalam web ini.seperti newsgroups, Google locked, FTP site, honeypots dan lain sebagianya seperti 4Chan. Situs ini dikategorikan mudah dijangkau.

4. Level 4 dikenal sebagai charter web atau Deep web. Hacker groups, aktifitas media terlarang dan lain sebagianya, situs ini biada disebut dengan web dalam yang dengan mesin pencariaan biasa tidak dapat menjangkaunya.

5. Level 5 dilevel ini segalanya sedikit menyeramkan. Tingkat ini dikenal sebagai Dark web yang melalui internet normal situs ini tidak dapat diakses, dalam mengakses situ ini diperlukan jaringan khusus seperti TOR
(The Onion Router). Didalam situs ini terdapat banyak kejahatan seperti bounty hunter, drugs, human trafficking, hacker exploits, black market, dan masik banyak kejahatan laiinya.

\section{c. Mengenal TOR (The Onion Router)}

Tor (The Onion Router) adalah jaringan anonim layaknya seperti bawang yang dirancang oleh karyawan di US Naval Researce Laboratory (NRL). Hal ini dimplementasikan dengan menggabungkan teknologi peer-to-peer $(P 2 P)$, dimana klien berkomunikasi dalam one-to-one, dengan teknologi Sock dalam menyampailkan TCP/IP dalam berkomunikasi. Nod relay Tor tersebar diseluruh dunia dan jaringan saat ini lebih dari 6000 server[11]. Tor browser menjadi salah satu Software browser yang open source digunakan untuk berselancar di internet khususnya Deep web. Tor browser dibangun melalui modifikasi mozilla dan memiliki pengaturan privasi dan keamanan tersendiri dengan konsep layaknya seuah bawang merah dan dapat mengakses situs .onion yang tidak dapat diakses oleh browser standar dan mesin pencari. Tor popular untuk kecepatan dan keamannya. Tor singkatan dari The Onion Router yang mengacu pada bawang dalam istilah teknis.

Tor merupakan software open source yang mudah untuk diunduh, dipasang, dan disetel. Software Tor dapat dipasang di OS Windows, Mac OS atau Linux dan bekerja pada semua jenis protokol internet seperti, HTTP, FTP, gopher dan lain-lain. Tor menyediakan kemampuan penelusuran canggih yang disebut "hidden service" untuk mendukung penelusuran anonime

\section{d. Mengenal dot Onion (.onion)}

Dot onion (.onion) merupan domain dari Dark Web .onion memperoleh nama sebagia data yang dikirim melewati berbagia lapisan enkripsi dan dekripsi layaknya lapisan bawang ketika dialihkan dari sumber ke tujuan. Tujuan dari penggunaan sistem ini adalah untuk membuat penyedia informasi dan orang yang mengakses informasi lebih sulit terdeteksi atau terlacak, oleh host jaringan menengah, atau oleh orang luar. Akan tetapi browser web seperti Tor dapat mengakses situs dot onion (.onion) dengan mengirim permintaan melalui jaringan server Tor dengan pemasangan perangkat lunak proxy yang sesuai. Mesin pencari Deep Web terhubung ke layanan lapisan onion melalui Tor dan relay dan kemudian memberikan hasil pencarian akhir ke browser di Surface Web[8].

\section{e. Text Preprocesing}

Tahapan seleksi pada sebuah data yang akan diseleksi pada sebuah dokumen, dalam memudahkan mengelola sebuah data yang belum terstruktur menjadi data yang terstruktur sesuan dengan 
kebutuhan. proses text preprocessing terdiri dari beberapa tahap sebagai berikut :

1.Pertama, Case Folding, merupakan proses pengubahan huruf pada sebuah dokumen menjadi satu bentuk, misalnya merubah huruf kapital dijadikan huruf kecil dan begitupun sebaliknya

2.Kedua,Tokeninzing, proses pemisahan teks menjadi potongan kalimat dan kata yang disebut token.

3. Ketiga, Filtering, proses dimana membuang kata dan tanda baca yang kurang bermakna secara signifikan, seperti penghilangan tanda hashtag (\#), url dan tanda baca laiinya.

f. Langkah-Langkah Penelitian

Penelitian ini dilakukan dengan men-capture halaman-halaman Dark Web, dimana hasil capture halaman-halaman Dark Web kemudian akan analisis menggunakan preprocesing text dan menganalisis vendor yang berkaitan dengan frekuensi kata tertinggi. Untuk mendapatkan data dalam penelitian ini menggunakan salah satu aplikasi yaitu Hunchly. Adapun tahapan yang dilakukan pada penelitian ini melalui beberapa tahapan sebagia berikut :

\section{Studi Pustaka}

Studi pustaka dilakukan pada langkah awal untuk menghimpun informasi yang relevan dengan topik atau masalah yang akan diteliti. Sumber-sumber informasi pada studi pustaka dapat diperoleh melalui bukti fisik-bukti fisik yang memiliki keterkaitan dengan masalah yang akan diteliti, jurnal ilmiah serta sumber-sumber informasi lainnya yang dapat diperoleh melalui internet.

\section{Analisa Kebutuhan Tools}

Tahapan ini dilakukan untuk menganalisis kebutuhan tools yang akan digunakan dalam penelitian meliputi proses-proses apa saja yang nantinya dapat dilakukan oleh tools yang dibutuhkan dalam analisis halaman-halaman Dark web, dalam hal ini penelitian menggunakan aplikasi Hunchly dan Orange dalam menganalisis untuk mendukung investigasi kejahatan, disamping itu dbutuhkan jaringan khusus dalam mengakses Dark Web yaitu menggunakna jaringan TOR (The Onion Router) dan plugin Hunchly yang ter-install pada browser Chrome.

\section{Installasi dan Konfigirasi}

Tahapan ini dilakukan untuk menganalisis kebutuhan tools yang akan digunakan dalam penelitian meliputi proses-proses apa saja yg nantinya dapat dilakukan oleh tools yang dibutuhkan dalam menganalisis halaman-halaman Dark Web dalam mendukung investigasi Kejahatan, dalam hal ini penelitian menggunakan aplikasi Hunchly dalam men-capture halaman-halaman Dark Web, disamping itu configurasi jaringan menggunakan jaringan TOR (The Onion Router) agar dapat mengakses halaman-halaman Dark Web.

\section{Pengumpulan Data}

Tahapan selanjutnya adalah mendapatkan data halaman Dark Web dengan men-capture halamanhalaman Dark Web menggunakan aplikasi Hunchly. Proses mengumpulkan informasi dan data sebagai pendukung penelitian ini perlu ditetapkan tujuan yang melatarbelakanginya. Dengan menginputkan selector pada aplikasi Hunchly diharapkan dapat mengumpulkan data yang relevan.

\section{Analisa Data}

Dalam prose pengolahan datanya, hasil capturing halaman Dark Web berupa data halaman dan data jumlah capture berdasarkan selector yang ditampilkan pada Desktop Hunchly, data halaman hasil capture brupa file ".mhtml" yang kemudian dirubah menjadi .html dan di convet menjadi ".txt" dalam memudahkan Analisa data. Selanjutnya hasil convet data berupa ".txt" dilakukan analisa data menggunkan preprocessing text untuk mengetahui jumlah kata dari halaman yang berhasil dicapture menggunakan aplikasi orange dimana data tersebut dilakukan Case Foledering yaitu proses pengubahan huruf dalam dokumen menjadi satu bentuk, misalnya huruf kapital dijadikan huruf kecil dan sebaliknya, selanjutnya dilakuakan tokenizing proses pemisahan teks menjadi potongan kalimat dan kata yang disebut token, dan selanjutnya filtering yaitu proses dimana membuang kata dan tanda baca yang kurang bermakna secara signifikan, seperti penghilangan tanda hashtag (\#), url dan tanda baca lainnya tujuan dari proses ini memperoleh data yang lebih terstruktur.

\section{Kesimpulan dan Saran}

Tahapan ini merupakan tahapan akhir untuk menyampaikan kesimpulan dari temuan-temuan yang diperoleh selama penelitian. Laporan yang disusun diharapkan dapat memberikan gambarandan informasi secara menyeluruh mengenai topik penelitian ini serta dapat memberikan rekomendasi yang bermanfaat untuk penelitian selanjutnya.

\section{HASIL DAN PEMBAHASAN}

Proses pengumpulan data halamana-halaman Dark Web yaitu dengan men-capture halamanhalaman Dark Web menggunkan aplikasi Hunchly dimana pada aplikasi Hunchly telah terinput selector, halaman-halaman Dark Web yang telah dikunjungi dan kemudian selector akan menghitung halaman bedasarkan kata yang telah diinputkan pada selector Hunchly. Dalam hal ini peneliti menggolongkan selector berdasarkan case yang bebeda. Pada case DarkMarket 70 selector, case CyperMarket 42 selector dan Case ApollonMarket 58 selector kata yang dicari pada aplikasi Hunchly dengan tujuan memilah halaman yang relevan untuk dianalisis. Proses alur pengumpulan data seperti yang terdapat pada Gambar 1. 


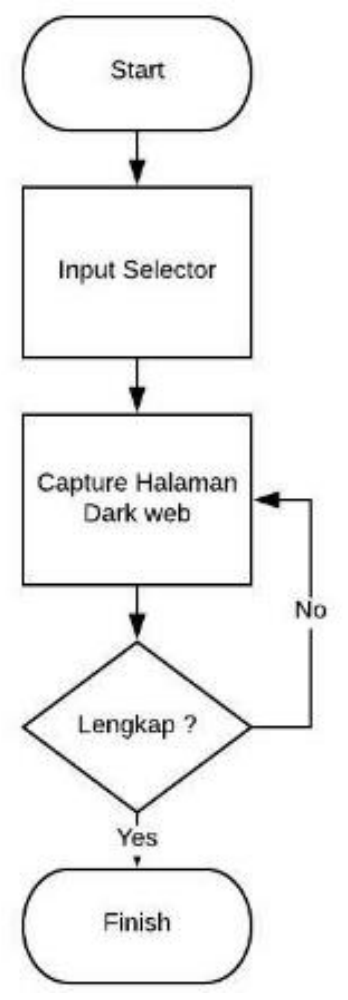

Gambar 1. Proses Pengumpulan Data

Contoh hasil capture halaman Dark Web pada Gambar 2.

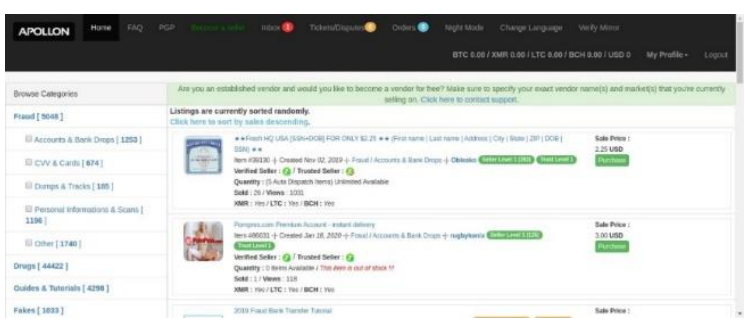

Gambar 2. Contoh capture halman Dark Web

Setelah data halaman-halaman Dark Web berhasil di capture dilanjutkan dengan menganalisa hasil capture halaman-halaman Dark Web, data yang diperoleh dari hasil capture disajikan pada Tabel 1

Tabel 1 Hasil capture halaman Dark Web

\begin{tabular}{cccc}
\hline No & Halaman & Selector & $\begin{array}{c}\text { Periode } \\
\text { Capturing }\end{array}$ \\
\hline 1 & 5413 pages & 162 & 15 April 2020 \\
- & 06 Mei 2020 \\
\hline
\end{tabular}

Pada penelitian ini data yang diperoleh pada Tabel 1 kemudian dilakukan preprocessing text menggunakan aplikasi orange dengan tujuan menseleksi data agar data yang dipeloleh menjadi lebih terstruktur contoh hasil preprocessing text dari hasil ekstraksi data yang disajikan pada Gambar 3.

\begin{tabular}{|c|c|c|c|c|c|}
\hline & Word & Word Count & & Word & Word Count \\
\hline 1 & ) & $2.32069 \mathrm{e}+06$ & 1 & drugs & 69162 \\
\hline 2 & ( & $2.31656 e+06$ & 2 & hashish & 63804 \\
\hline 3 & $=$ & $1.95867 e+06$ & 3 & cannabis & 63254 \\
\hline 4 & : & 757889 & 4 & stimulants & 42732 \\
\hline 5 & $>$ & 672172 & 5 & security & 41656 \\
\hline 6 & $3 d$ & 655967 & 6 & psychedelic & 36606 \\
\hline 7 & 1 & 522834 & 7 & goods & 35616 \\
\hline 8 & 09 & 294144 & 8 & c3 & 31779 \\
\hline 9 & & 254471 & 9 & opiates & 31131 \\
\hline 10 & 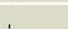 & 235440 & 10 & ecstasy & 30857 \\
\hline
\end{tabular}

Gambar 3. Hasil ekstraksi data halaman-halman Dark Web

Dari Gambar 3 dapat dilihat kata "drugs" memiliki frekuensi tertinggi dengan 69162 kata dari hasil ekstraksi halaman Dark Web yang berhasil tercapture. Visualisasi menggunakan wordcloud berdasarkan kata seperti pada Gambar 4.

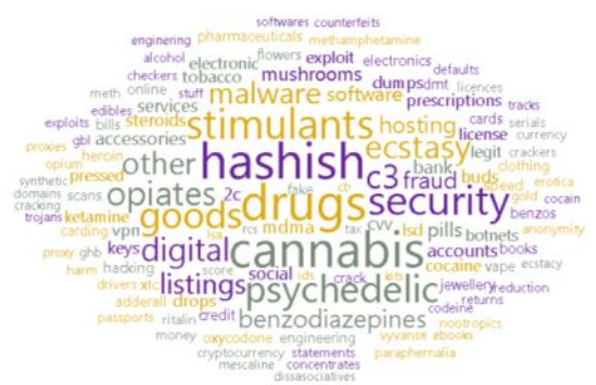

Gambar 4. Visualisasi berdasarkan banyaknya kata hasil capture halaman-halaman Dark Web

Berdasarkan hasil yang diperoleh seperti pada Gambar 4 hasil preprocessing text kemudian di klasifikasikan berdasarkan kategori dan divisulkan untuk melihat persentase dari masing-masing kategori. Hasil visualisas i persentase frekuensi kata seperti pada Gambar 5.

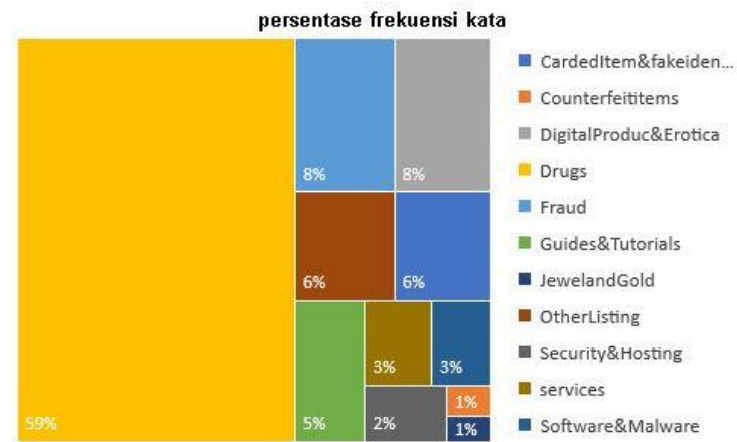

Gambar 5. Persentase frekuensi kata

Berdasarkan hasil yang diperoleh pada perhitungan preprocessing text menggunakan aplikasi orange kata "drugs" memiliki persentase $59 \%$, oleh sebab itu analisis terhadap vendor yang berkaitan dengan kata "drugs" menjadi prioraitas yang menjadi frekuensi kata paling besar. Selanjutnya dilakukan analaisis pada vendor, tahapan pertama yang dilakukan adalah dengan menganalisa pada vendor yang berhubungan dan menjual produk terkait 
dengan "drugs" Berikuat salah satu contoh gambar profil vendor yang menjual "drugs" seperti yang terdapat pada Gambar 6

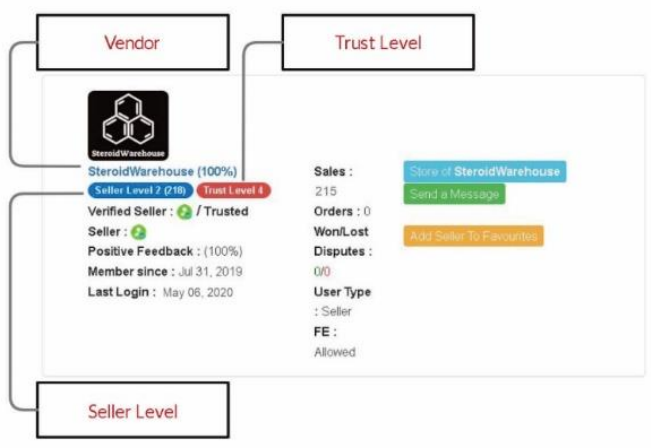

Gambar 6. Vendor, Seller level dan Trust level

Tahapan berikutnya adalah melakukan analisa lebih mendalam terkait profil dari vendor tersebut seperti TrusLevel dan SellerLevel, Pada Gambar 6 dapat dilihat berupa data dari salah satu profil vendor pada halaman Dark Web yang berhasil ter-capture, pada tahapan proses selanjutnya dilakukan Analisa informasi data terkait email dan informasi-informasi lainnya yang dapat mendukung investigasi kejahatan, dalam hal ini aplikasi Hunchy mampu mengkategorikan data yang didapat dari hasil capturing halaman-halaman Dark Web berupa email dan url Dark Web yang terdapat pada halaman tersebut, contoh data yang diperoleh dari hasil capturing halaman Dark Web pada Gambar 7.

\begin{tabular}{|c|c|c|c|}
\hline (i) Info & EPath & D Notes (1) & a. Photos 0 \\
\hline Type & Category & value & \\
\hline Darkweb & Tor Hildden Servite & apollonujpesjing.onion & \\
\hline Darkweb & Tor Hildden Service & steroidwa7ppaligw.onion & \\
\hline Accounts & Emailiaddress & 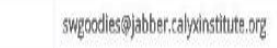 & \\
\hline Accounts & Email Address & swgoodiesepprotonmail.com & \\
\hline
\end{tabular}

Gambar 7. Data Hasil Capturing Hunchly

Data yang dipeorleh dari hasil analisis empat vendor yang terkait dengan "drugs", berikut daftar empat vendor dan data hasil analisis halaman Dark Web menggunkan Hunchly disajikan pada Tabel 2.

Tabel 2 Daftar vendor dan data Dark Web

\begin{tabular}{|c|c|}
\hline Vendor & Data \\
\hline SteroidWarehouse & $\begin{array}{l}\text { - } \text { swgoodies@jabber.calyxinstitute.org } \\
\text { - swgoodies@protonmail.com } \\
\text { - www.swgoodies.com } \\
\text { - } \text { Steroidwa7pp4igw.onion }\end{array}$ \\
\hline luck0923 & 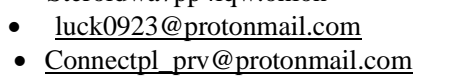 \\
\hline ConnectPL & $\begin{array}{l}\text { - Pan.kowalski@gmail.com } \\
\text {-_prv@protonmail.com }\end{array}$ \\
\hline VanillaSurf & - vanillasurf@protonmail.com \\
\hline
\end{tabular}

Contoh detail hasil analisis vendor dari hasil analisis halaman Dark Web dalam mendukung investigasi kejahatan seperti yang terdapat pada Gambar 8 dan Gambar 9

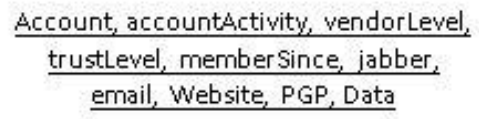

Gambar 8. Struktur data vendor

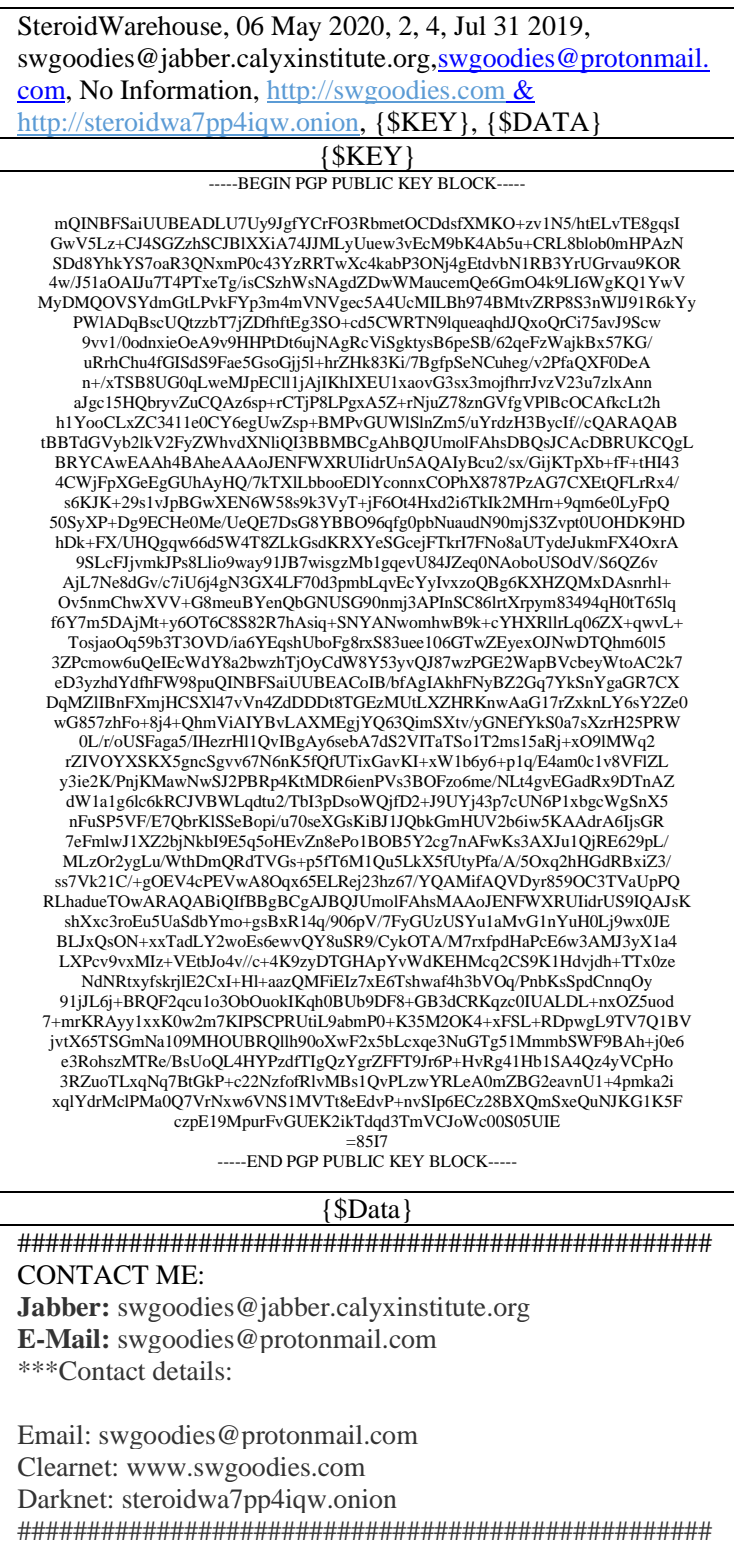

Gambar 9. Contoh hasil analisis data vendor

Berdasarkan analisis yang dilakukan menggunkan preprocessing text pada hasil capture halaman-halaman Dark Web dapat mengetahui prekuensi kata yang paling sering digunakan sehingga dapat menjadi dasar sekala prioritas peneliti terkait vendor yang akan dilakukan analisis halaman Dark Web dalam mendukung investigasi kejahatan. 
Pada penelitian ini, sifat Dark Web yang terenkripsi berlapis dan anonim [12] menjadikan Dark Web tidak terindeks dimesin pencarian pada umumnya seperti google, bing, dan yahoo memerlukan analisis langsung pada halamanhalaman Dark Web, dengan menganlisis halaman Dark Web secara langsung dapat membantu dalam melakukan analisis halaman Dark Web dalam mendukung investigasi kejahatan. Dengan menggunakan aplikasi Hunchly maka mendapatakan informasi pada halaman Dark Web menjadi lebih efisien. Selector yang terinput pada aplikasi Hunchly memudahkan dalam memperoleh data, memilah dan menganalisis halama-halaman Dark Web.

\section{KESIMPULAN}

Berdasarkan hasil penelitian yang telah dilakukan, untuk mejawab pertanyaan peneliti yang telah dikemukakan diawal, maka dapat diambil kesimpulan bahwa menganalisis halaman-halaman Dark Web menggunakan Hunchly dapat digunakan untuk melakukan analisa investigasi pada halaman Dark Web, dimana dari analisa halaman Dark Web ditemukan salah satu produk yang paling sering dijual yaitu "drugs" serta profil vendor. Data selector yang terinput pada aplikasi Hunchly, dapat dijadikan sebagai dasar untuk mendapatkan informasi dari halaman Dark Web. Yang selanjutnya dilakukan analisa untuk mendapatkan informasi lebih mendalamdari tiap-tiap halaman Dark Web. Berdasarkan hasil pada penelitian ini, didapatkan informasi yang penting untuk melakukan investigasi pada halaman Dark Web, seperti informasi tentang profil pegguna, vendor level, trust level, membersince, jabber, email, website, PGP yang semuanya dapat memberikan informasi terkait data yang dapat dijadikan sebagian salahsatu barang bukti dalam mendukung investigasi kejahatan. Dari hasil penelitian, ditemukannya email vendor pada akun terkait sehingga perlu dilakukan investigasi yang kebih jauh terhadap akun untuk mendaatkan informasi yang relevan.

\section{DAFTAR PUSTAKA}

[1] B. A. Abduljalil,. 2017 'Critical Analysis of the Emerging Dark Web’, (April).

[2] European Monitoring Centre for Drugs and Drug Addiction., 2017. Drugs and the darknet. doi: $10.2810 / 783427$.

[3] K. Finklea., (2017) 'Dark Web Kristin Finklea Specialist in Domestic Security', Dark Web. Available https://fas.org/sgp/crs/misc/R44101.pdf.

[4] M. Ganesan and P. Mayilvahanan., 2017. 'Cyber Crime Analysis in Social Media Using Data Mining Technique’, International Journal of Pure and Applied Mathematics, 116(22), pp. 413-424. Available at: http://www.ijpam.eu.

[5] J. R. Harrison., D. L. Roberts and J. HernandezCastro., 2016. 'Assessing the extent and nature of wildlife trade on the dark web', Conservation Biology, 30(4), pp. 900-904. doi: 10.1111/cobi.12707.

[6] G. Hurlburt,. 2017. 'Shining light on the dark side of the Dark web', IEEE Computer Society, 1(1). Available at: https://neurofantastic.com/brain/2017/1/12/shin ing-light-on-the-dark-side-of-oxytocin.

[7] K. Kautsarina,. 2019. 'Perkembangan Riset Etnografi Di Era Siber: Tinjauan Metode Etnografi Pada Dark Web', Masyarakat Telematika Dan Informasi: Jurnal Penelitian Teknologi Informasi dan Komunikasi, 8(2), p. 145. doi: 10.17933/mti.v8i2.109.

[8] L. D. Larry Daniel,. 2012. "Digital Forensic For Legal Profesionals.

[9] D. Rathod,. 2017 'Darknet Forensics', International Journal of Emerging Trends \& Technology in Computer Science (IJETTCS), 6(4), pp. 77-79.

[10] P. Shakarian, P. 2018. 'Dark-web cyber threat intelligence: From data to intelligence to prediction', Information (Switzerland), 9(12), pp. 9-10. doi: 10.3390/info9120305.

[11] S. Suneetha,. (no date k) 'UNVEILING DEEP WEB , A HIGH-QUALITY , QUANTITATIVE INFORMATION RESOURCE', (2), pp. 167174.

[12] I. yuliana, 2019. 'Adopsi Social Network Analysis (Sna) Dalam Upaya Membangun Ketangguhan Bencana Di Masyarakat', JIKO (Jurnal Informatika dan Komputer), 2(2), pp. 49-54. doi: 10.33387/jiko.v2i2.1312.

[13] D. R. Hayes, F Cappa dan J. Cardon (20181) 'A Framework for More Effective Dark WebMarketplace Investigations', Information, 9, pp. 1-17. doi: https://doi.org/10.3390/info9080186.

[14] A. Deb, K. Lerman dan E. Ferrara., (2018) Predicting Cyber-Events by Leveraging Hacker Sentiment. Information, 9, pp. 1-18. doi: doi:10.3390/info911028

[15] E. Nunes, et.al., 2016. Darknet and Deepnet Mining for Proactive Cybersecurity Threat Intelligence, Available at: https://arxiv.org/pdf/1607.08583.pdf 